\title{
Effect of electric current on the oil-contaminated soil
}

\author{
(C) Nikolay S. Shulaev, ${ }^{*}$ Valeriya V. Pryanichnikova, ${ }^{+}$Ramil R. Kadyrov, \\ Nikolay A. Bykovsky, and Inna V. Ovsyannikova \\ Ufa State Petroleum Technical University in the City of Sterlitamak. Pr. Oktyabrya St., 2. \\ Sterlitamak, 453118. Republic of Bashkortostan. Russia. Phone: +7(9033) 56-98-91. \\ E-mail:prvaleria@mail.ru.
}

\begin{abstract}
*Supervising author; ${ }^{+}$Corresponding author
Keywords: electrochemical cleaning, oil products, soil, electrokinetic processes, electrooxidation, voltage, electrodes.
\end{abstract}

\begin{abstract}
Electrochemical treatment of contaminated soils is an actual method for the remediation of industrial and urban areas. It represents a good alternative to methods of mechanical, thermal, chemical and biological treatment, and, if necessary, can be used with them. Passing electric current through the soil allows to reduce the concentration of such pollutants as oil and oil products at a considerable depth, to successfully reduce the content of dissolved mineral salts. In recent years a number of works of scientists around the world have been devoted to the study of such technologies. This article discusses the results of experimental studies conducted in the Russian Federation, Romania, Italy, the United States of America and some other countries. A review is given of various options for implementing the electrical treatment of soils contaminated with oil, diesel fuel and oil-containing waste using various types and sizes of electrochemical cells, as well as a variation in the sizes, shapes and materials of the electrodes used (cathodes and anodes). When modeling processes occurring in the soil and induced by electric current, the most significant monitoring parameters are the hydrogen index (soil acidity), amperage and voltage, soil resistance and electrical conductivity, redox potential, and the concentration of pollutants. When assessing the appropriateness of applying electric cleaning methods, the value of energy costs and the efficiency (degree) of cleaning the treated soil are of high importance, therefore, special attention is paid to their analysis.

Also the results of author's research in this field are presented in this work. The results of cleaning model soils of various types are considered, mathematical calculations of some of the most important process parameters are given. A specific arrangement of electrodes in wells in vast areas of soil with various concentrations of pollutants is proposed, which allows achieving optimal cleaning results for all areas simultaneously using a single power source without additional energy and, accordingly, material costs.
\end{abstract}

\section{References}

[1] V. Gingine, R.P. Shah, R. Koteswar, P. Hari Krishna. A review on study of Electrokinetic stabilization of Expansive soil. Int. Journal on Earth Science and Engineering. 2013. No.2. P.176-181.

[2] A.V. Zhelovitskaya, E.A. Ermolaeva, A.F. Dresvyannikov. Oxidation of organic compounds with a hydroxide radical generated in solutions by chemical and electrochemical methods. Bulletin of Kazan Technological University. 2008. No.6. P.221-229. (russian)

[3] J.K. Wittle, S. Pamukcu, D. Bowman, L.M. Zanko and F. Doering. Field studies on sediment remediation. Electrochemical remediation technologies for soil, sediment and ground water - Hoboken: Wiley \& Sons, Inc. P.661-696.

[4] C. Streche, D.M. Cocârță1, I.A. Istrate and A.A. Badea. Decontamination of Petroleum-Contaminated Soils Using The Electrochemical Technique: Remediation Degree and Energy Consumption. Scientific Reports. 2018. №8:3272. DOI:10.1038/s41598-018-21606-4 2018

[5] D.M. Cocar $\square$ a, I.A. Istrate, C. Streche, D.M. Dumitru. Removal of Total Petroleum Hydrocarbons from Contaminated Soils by Electrochemical Method. World Academy of Science, Engineering and Technology International Journal of Environmental and Ecological Engineering. 2017. Vol.11. No.5. P.469-473.

[6] I.A. Istrate, T. Apostol, A. Badea. An alternative to the treatment of leachate contaminated soil. Ecoterra. 2014. No.11(2). P.78-84. 
[7] S. Jamaly, A. Giwa, S.W. Hasan. Recent improvements in oily wastewater treatment: Progress, challenges, and future opportunities. Journal of environmental sciences. 2015. No.37. P.15-30.

[8] B.K. Korbahti, K. Artut. Electrochemical oil/water demulsification and purification of bilge water using Pt/Ir electrodes. Desalination. 2010. No.258(1-3). P.219-228.

[9] E. Ferrarese, G. Andreottola. Application of electrochemical techniques for the remediation of soils contaminated with organic pollutants. Proceedings of the Annual International Conference on Soils, Sediments, Water and Energy. 2010. No.13

http://scholarworks.umass.edu/soilsproceedings/vol13/iss1/26

[10] V.V. Pryanichnikova, N.S. Shulaev, N.A. Bykovsky, R.R. Kadyrov. The electrochemical method of oilcontaminated soil remediation. Key Engineering Materials. 2017. Vol.743. P.314-318.

[11] V.V. Pryanichnikova, N.S. Shulaev, N.A. Bykovsky, and R.R. Kadyrov. Electrochemical cleaning of oil-contaminated soil. Butlerov Communications. 2016. Vol.47. No.7. P.47-51. DOI: 10.37952/ROI-jbc01/16-47-7-47

[12] V.V. Pryanichnikova, N.S. Shulaev, N.A. Bykovskiy, and R.R. Kadyrov. The features of the electrochemical cleaning of different types of oil-contaminated soil. Butlerov Communications. 2018. Vol.53. No.3. P.124-129. DOI: 10.37952/ROI-jbc-01/18-53-3-124

[13] V.V. Pryanichnikova, N.S. Shulaev, N.A. Bykovsky, R.R. Kadyrov Calculation of electrical parameters during electrochemical cleaning of oil-contaminated soils. Fundamental research. 2018. No.12-2. P.208-212. (russian)

[14] V.P. Meshalkin, N.S. Shulaev, V.V. Chelnokov, V.V. Pryanichnikova and R.R. Kadyrov. Determination of electrical parameters for the electrochemical treatment of soils contaminated with oil. IOP Conference Series: Materials Science and Engineering. 2019. No.537 (062069) DOI:10.1088/1757-899X/537/6/062069. 